\title{
Effectiveness of Sansavieria trifasciata Extract Bracelet in Absorbing Carbon Monoxide (Co) in Cigarette Smoke
}

\author{
Gendis Siti Rahmawati $^{1}$, Resti Nuraeni ${ }^{1}$, Lu'lu Robiatul Fajrin' ${ }^{1}$, Sistiana Windyariani ${ }^{1}$ \\ ${ }^{1}$ Prodi Pendidikan Biologi, Fakultas Keguruan dan Ilmu Pendidikan, Universitas \\ Muhammadiyah Sukabumi \\ *e-mail: gendissiti10@gmail.com
}

\section{Article Info}

Key word:

Carbon monoxide;

cigarette smoke;

Sansevieria trifasciata

\section{Article history:}

Received:16-06-2019

Revised: 07-10-2019

Accepted: 28/11/2019

\begin{abstract}
Carbon monoxide (CO) contained in cigarette smoke is a very strong poison, if it is smoked by the lungs it will be easier to bind hemoglobin, so that red blood cells will lack oxygen, which can cause damage to blood vessels. with the process of atherosclerosis (narrowing). Sansevieria trifasciata has the ability to absorb poisons such as CO. This study aims to determine the effectiveness of Sansevieria trifasciata leaf extract in absorbing $\mathrm{CO}$ contained in cigarette smoke and assessing the amount of $\mathrm{CO}$ absorbed by Sansevieria trifasciata leaf extract. The method used is a pure experimental method using a Completely Randomized Design (CRD) consisting of 3 different treatments and 3 repetitions. The results of the 3 treatments showed that $P 1$ (Sanseviera trifasciata wet extract) had the ability to absorb $C O$ an average of 12.67 ppm every 15 minutes, in contrast to $P 2$ (ethanol extract of Sanseviera trifasciata) which absorbs CO. 91.11 ppm every 15 minutes $P 3$ (ethanol extract and CMC leaves from Sansevieria trifasciata) has the ability to absorb CO by 37.89 ppm every 15 minutes. The highest absorption effectiveness was obtained by ethanol extract and bracelets containing ethanol extract with the addition of CMC.
\end{abstract}

\section{Introduction}

According to the facts of Indonesian tobacco, it is estimated that $5 \%$ of women in Indonesia smoke, in addition to being active smokers, there are far more women who become passive smokers. An estimated 65.6 million women and 43 million children in Indonesia are exposed to cigarette smoke. This happens because $91 \%$ of smokers smoke inside the house, not far from their wives and children (Mahdalena et al., 2014). 65\% of parents, especially the head of the household, still smoke inside the house. This activity causes children to be exposed to cigarette smoke, which disrupts their health (Bastiandy, 2016). In 2012, the Health Promotion Section of the Sukabumi City Health Office once examined around 300 civil servants who were active and passive smokers. As a result, the health condition of passive smokers is not much different from active smokers, meaning that this condition indicates if the passive smoker is exposed to the effects of smoke from active smokers in the room (Qodri et al., 2016). 
Cigarette smoke is inhaled by active smokers and passive smokers, containing gas and particle components. The gas component consists of nitrogen and hydrocarbon compounds, while particle components some of which consist of tar, nicotine, benzopirene, phenol and cadmium. But there are 3 main toxic components contained in cigarette smoke, namely carbon monoxide, nicotine, and tar (Batubara et al., 2013).

Carbon monoxide can enter the body in the maximum amount and in a short time. Carbon monoxide is a very strong poison, if it is sucked in by the lungs it will be easier to bind hemoglobin, so that red blood cells will lack oxygen. Cells that suffer from lack of oxygen will compensate for blood vessels by spasm. When the spasm process lasts long and continuously, the blood vessels will be easily damaged by the occurrence of the process of atherosclerosis (narrowing).

These problems can be overcome by using Sansevieria trifasciata plants, from the results of various studies showing that Sansevieria trifasciata holds many benefits for life. Sansevieria trifasciata is one of the special plants which has the ability to absorb toxins in the air including carbon monoxide, nicotine, benzene, formaldehyde, trichloroethylene and dioxin. Previous researchers have found that Sansevieria contains the pregnane glycoside active ingredient which functions to reduce pollutants to organic acids, sugars and amino acids which are no longer harmful to humans (Adawiyah et al., 2013).

There are many studies that have utilized Sanseviera trifasciata leaf extract to absorb various pollutants, especially in cigarette smoke, but this utilization is still difficult to reach by the community because it cannot be used directly and is not easy to carry anywhere, considering cigarette smoke is in public places. Based on this, this study aims to provide a solution to deal with these problems, namely by making a wristband containing Sanseviera trifasciata leaf extract that can absorb $\mathrm{CO}$ in cigarette smoke and measure its effectiveness in absorbing $\mathrm{CO}$ levels contained in cigarette smoke.

\section{Materials and methods}

\section{Research Design}

The type of research used is pure experiment. The research method used was quantitative with the research design used, namely using a completely randomized design (CRD) consisting of 3 treatments and 3 repetitions consisting of P1 (extraction with distilled water), P2 (extraction with ethanol), P3 (extraction with ethanol and $\mathrm{CMC}$ ). The maceration method was carried out to obtain Sansevieria trifasciata leaf extract.

\section{Population and research sample}

The sample in this study was Sansevieria trifasciata leaves obtained from the environment and yard of the house around the city of Sukabumi. The parameters observed were a decrease in CO levels after being extracted from Sanseviera trifasciata leaves.

\section{Materials and methods}

This research was carried out at the FIBIGEN Laboratory of Muhammadiyah Sukabumi University in March-June 2019. The tools used were knives, blenders, digital balance sheets, funnels, filters, filter paper, aluminum foil, $1000 \mathrm{ml}$ beaker glass, measuring cups $100 \mathrm{ml}$, bottles, CO. analyzer, water bath, oven, drop pipette, silica gel bracelet and tray. The main ingredient used is the leaves of Sansevieria trifasciata. Supporting materials are Sodium Carboxy Methil Cellulose (Sodium CMC), aquades, $96 \%$ ethanol and cigarettes.

Research procedures include preparation of extraction tools and materials, extraction process, preparation of bracelet making, $\mathrm{CO}$ absorption test and data analysis. Sansevieria trifasciata leaf extract was extracted with three different 
treatments namely aquadest, maseration using 96\% ethanol, maserated Sansevieria trifasciata leaf extract which had been given Sodium Carboxy Methil Cellulose (Sodium CMC). $4 \mathrm{~kg}$ of Sansevieria trifasciata leaves washed, drained, crushed into pieces, crushed using a blender, it aims to break down the cell walls of the plant so that the active compounds in it are expected to be maximally extracted by the solvent used.

The crushed Sansevieria trifasciata leaves are then divided into two, each weighing $2 \mathrm{~kg}$ to obtain a different treatment, namely wet extraction and maseration extraction. For wet extraction of $2 \mathrm{~kg}$ of Sansevieria trifasciata leaves which were blended as much as 2, they were squeezed and then separated the liquid extract and solid using filter paper. The extract is stored in a closed bottle in a room that is not exposed to sunlight until testing. For the maseration process, the remaining Sansevieria trifasciata leaf blender is $2 \mathrm{~kg}$. dried using oven for 30 minutes at $60^{\circ} \mathrm{C}$. The dried sample is blended back until it becomes powder. Then filtering is carried out, the filtering results are separated by 30 grams from each simplicia then immersed in $225 \mathrm{ml}$ of $96 \%$ ethanol for $3 \times 24$ hours at room temperature. So that there are five types of extract extracts.

At the first 24 hours and second, the immersion solvent is replaced by filtering the filtrate first. The filter is put together then the solvent is evaporated using a $60^{\circ} \mathrm{C}$ bath until it is extracted as

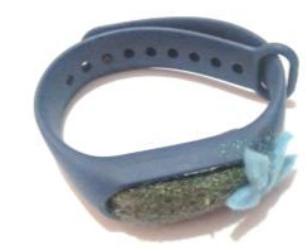

Figure 1. Silicon bracelet contains Sanseviria trifasciata Extract much as half of the initial volume. The extract is then stored in a closed bottle in a room that is not exposed to sunlight until testing.

The extraction of Sansevieria trifasciata leaves was made into a gel form by adding Sodium Carboxy Methil Cellulose (Sodium CMC) to be included in the formulation as Thickener (thickener) (Nurwaini \& Saputri, 2018). Sansevieria trifasciata leaf extract obtained with thick preparations changes to solid or jelly, making it easier in the packaging process on the wrist bracelet.

\section{Data Analysis}

The data analysis process carried out was measuring carbon monoxide levels in cigarette smoke using a $\mathrm{CO}$ analyzer before being given extract and after being given Sansevieria trifasciata leaf extract (Dewatisari, 2014). In addition, data analysis of $\mathrm{CO}$ absorption was performed on Sansevieria trifasciata leaf extract in the form of solids and Sansevieria trifasciata extract which had been inserted into the wristband.

The hand wristband made consists of two models namely, the first model of rubber band (silicon) in the middle is given a sansevieria extract that has been added with CMC and the second model is a knitting bracelet containing sansevieria extract which has been added with CMC, the sansevieria extract is wrapped by knitted yarn. made from woll yarn. For more details, the model of sansevieria extract bracelets made can be seen in (Figures 1 and 2) below.

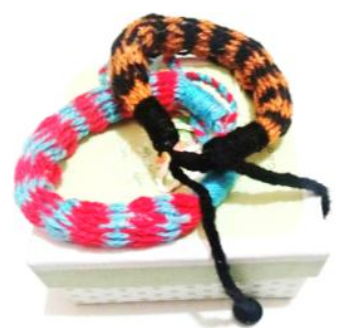

Figure 2. Knitting Bracelet contains Sanseviria trifasciata Extract

\section{Result and Discussion}


The results of the study with the aim to see the effectiveness of the extract Sanseviera trifasciata in reducing $\mathrm{CO}$ levels in cigarette smoke. Three types of extracts are used including; Sanseviera trifasciata wet extract or Sanseviera trifasciata (P1) aquadest extract, Sanseviera trifaciata ethanol extract (P2) and Sanseviera trifasciata ethanol extract were given CMC (P3). Cigarettes that have been burned ends are inserted into a series of $\mathrm{CO}$ test equipment to measure how much $\mathrm{CO}$ content is using a $\mathrm{CO}$ analyzer. Through the measurement of $\mathrm{CO}$ content for each treatment namely (P1, P2, and P3) treatment (P1) CO levels obtained previously were $124 \mathrm{ppm}$, in the treatment (P2) CO levels obtained previously were $892 \mathrm{ppm}$, whereas in the treatment (P3) CO levels obtained previously were 363 ppm.

Measurement of $\mathrm{CO}$ content in cigarette smoke lasts for 135 minutes with an interval of measurement every 15 minutes. Based on the results of research on treatment (p1) after 15 minutes showed a decrease in $\mathrm{CO}$ levels. The results of measurements of decreasing $\mathrm{CO}$ levels in the $\mathrm{p} 1$ treatment can be seen more clearly in (Figure 3) below.

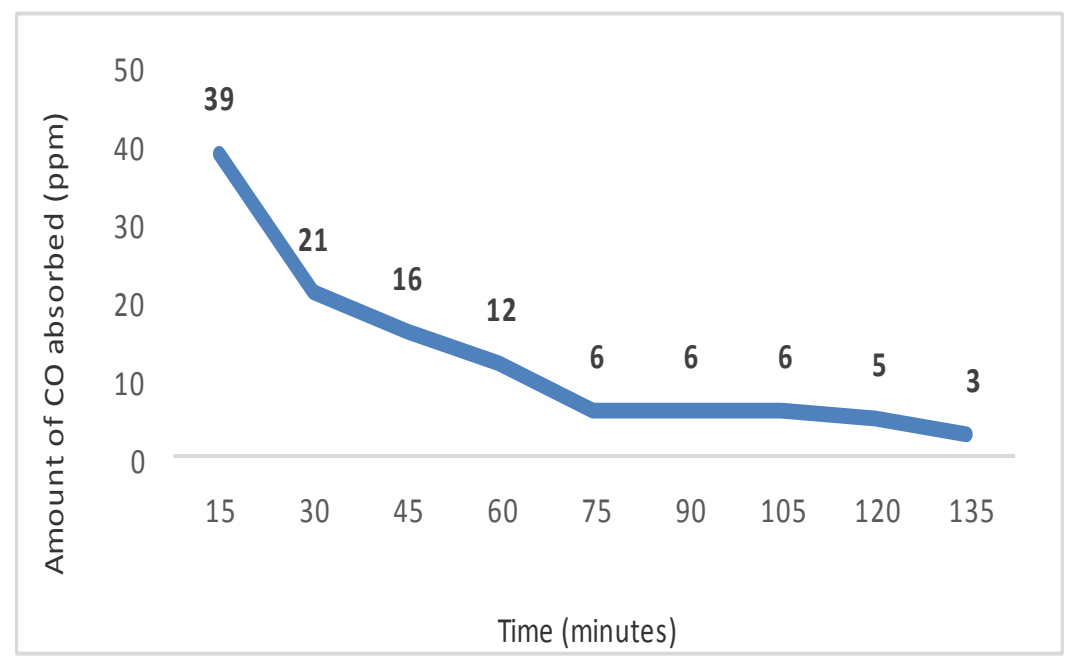

obtained different $\mathrm{CO}$ contents. In the

\section{Figure 3. Average CO. Absorption Rate by wet extraction of Sanseviera trifasciata}

Based on (Figure 3) above it can be seen that the result of a decrease in $\mathrm{CO}$ levels in $\mathrm{p} 1$ treatment for 135 minutes with each interval of 15 minutes shows an insignificant decrease. In the first 15 minutes the decrease was only 39 ppm. With an average $\mathrm{CO}$ absorption at $\mathrm{p} 1$ treatment for 135 minutes at $11.4 \mathrm{ppm}$. In addition, the quality of Sanseviera trifasciata extract obtained from the $\mathrm{p} 1$ treatment did not last long, after 24 hours the Sanseviera trifasciata extract had caused an unpleasant odor.
Sanseviera trifasciata extract in $\mathrm{p} 2$ treatment obtained the result of a decrease in $\mathrm{CO}$ levels which was more significant than Sanseviera trifasciata extract with $\mathrm{p} 1$ treatment. Based on the research results of Sansevieria trifasciata extract (with ethanol concentration of 96\%) obtained by maceration extraction from this $\mathrm{p} 2$ treatment after 15 minutes showed a decrease in CO levels very well. The results of measurements of decreasing $\mathrm{CO}$ levels in the p2 treatment can be more clearly seen in (Figure 4) below. 


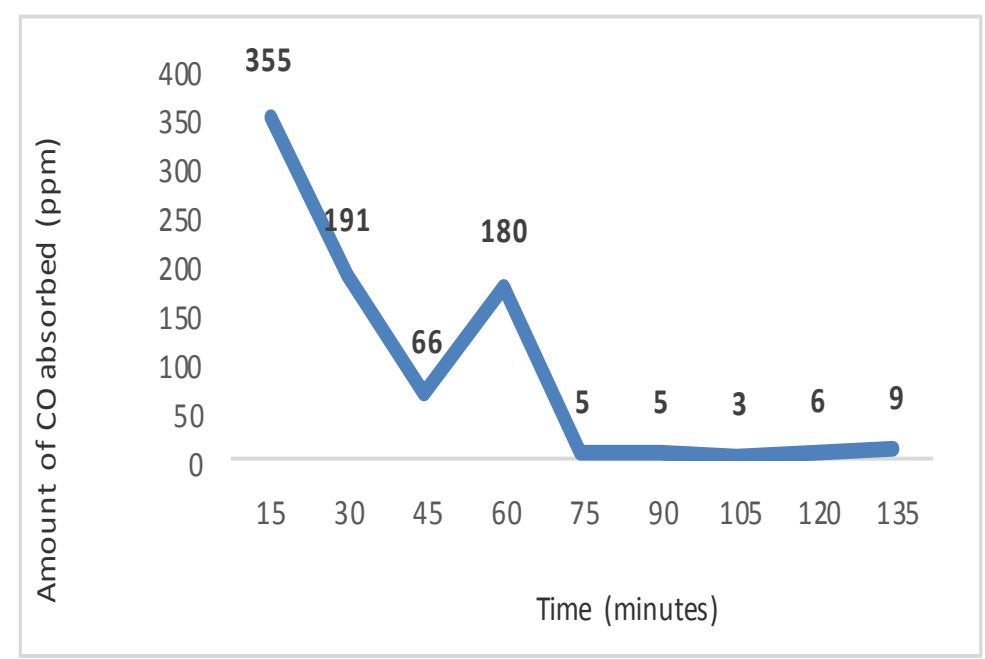

Figure 4. Average absorption of CO content by ethanol extract of Sanseviera trifasciata

Based on (Figure 4) above it can be seen that the decrease in $\mathrm{CO}$ levels in the treatment of $\mathrm{p} 1$ for 135 minutes with each interval of 15 minutes shows a very significant decrease. In the first 15 minutes the decrease in CO levels obtained was $355 \mathrm{ppm}$. With an average $\mathrm{CO}$ absorption in the p2 treatment for 135 minutes is 82 ppm. In addition, Sansevieria trifasciata extract obtained in p2 treatment using ethanol with a concentration of $96 \%$ has the advantage that the extract results are more durable, about 3 months more the quality of the extract is still of good quality. This is consistent with the opinion according to Sa'adah and Nurhasnawati, (2015) that ethanol used as a solvent is more effective, molds and germs are difficult to grow in ethanol $20 \%$ and above.

The effectiveness of smoke absorption by the Sanseviera plant is proven by research conducted by the United States Aeronautics and Space Administration, Sanseviera is one of the plants absorbing toxic gases, such as carbon monoxide contained in cigarette smoke (Rosha et al., 2013). When compared to the extraction process in treatment 1 with treatment $p 2$, based on the image $\mathrm{p} 2$ above the $\mathrm{CO}$ absorption process is more carried out in the extraction process with treatment p2 namely the extraction process with the use of ethanol compared to treatment $\mathrm{p} 1$ ie extraction with aquades this is due to the active ingredient from Sansevieria trifasciata namely pregnane glycoside which functions to absorb pollutants, one of which $\mathrm{CO}$ has been extracted properly. This is in accordance with the opinion Sa'adah \& Nurhasnawati, (2015) ethanol can dissolve alkaline alkaloids, evaporated oils, glycosides, curcumin, coumarin, anrakinon, flavanoid, steroids, dammar and chlorophyll.

However, the extract results in this P2 treatment have disadvantages, because the extract results are still in liquid form, so it has not been effective when applied in a bracelet product. So that the treatment of p3 extract Sansevieria trifasciata was given the addition of $\mathrm{CMC}$ to be more easily applied to the bracelet made because the extract form had changed to gel.

In the extraction process of Sansevieria trifasciata in p3 treatment, namely the extraction process using $96 \%$ ethanol and added CMC the results of $\mathrm{CO}$ reduction were lower than treatment 2 but faster than treatment 1 . The results of the reduction can be seen in (Figure 5) below. 


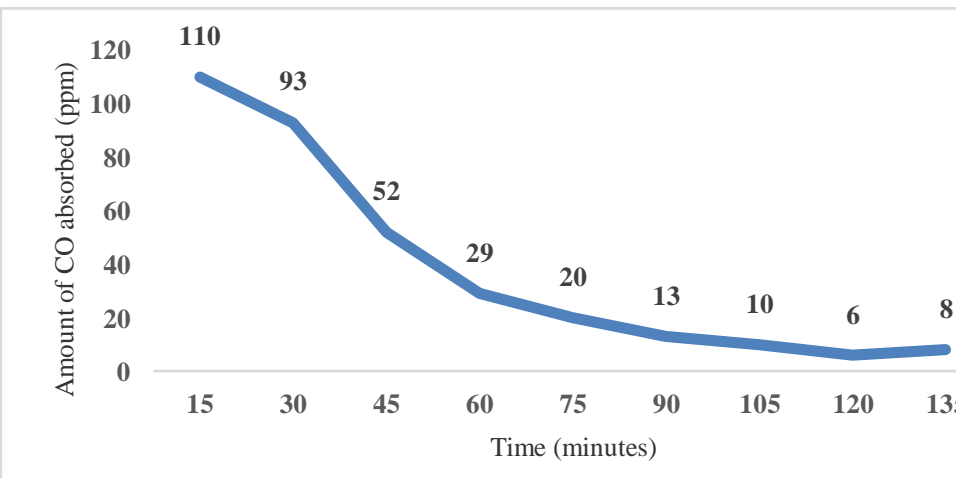

\section{Figure 5. Average absorption of CO content by extract ethanol + CMC Sanseviera trifasciata}

Based on (Figure 5) above it can be seen that the reduction in $\mathrm{CO}$ levels of Sansevieria trifasciata extract at p3 treatment for 135 minutes with an interval of every 15 minutes is quite significant. In the first 15 minutes a decrease in $\mathrm{CO}$ levels obtained by $110 \mathrm{ppm}$. With an average absorption of CO levels for 135 minutes at $34.1 \mathrm{ppm}$. This shows a better average number compared to Sansevieria trifasciata extract in $\mathrm{p} 1$ treatment with a difference of 22.7 ppm. In addition, Sansevieria trifasciata extract in p3 treatment also has the advantage of being easier to form because of its gel-like texture so that it is easily applied to the bracelet. In addition to the $\mathrm{p} 3$ treatment, the extraction results last longer for 3 months, the quality of the extract is still of good quality, this is because the previous extraction has been dissolved in $96 \%$ ethanol and the addition of CMC which also functions as a preservative.

From the three treatments used, it can be concluded that the results of the three treatments show that all the extraction treatments of Sansevieria trifasciata leaves have the ability to absorb CO. Sanseviria trifasciata leaves can absorb $\mathrm{CO}$ because they contain pregnane glycoside. The mechanism of absorption of pollutants by pregnane glycoside extracts occurs physically and chemically, this is evidenced by changes in the maximum wavelength and its ultraviolet spectra profile (Julianto et al. 2015). But of the three treatments showed different rates of decline. The following average results of comparison of $\mathrm{CO}$ absorption from the 3 different extraction treatments can be seen more clearly in the following (Figure 6).

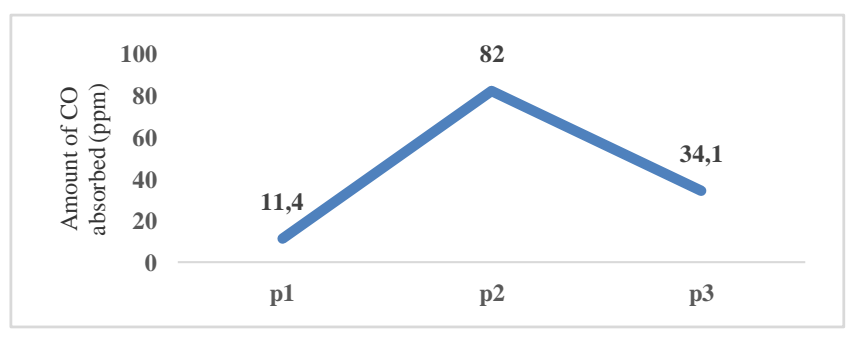

Figure 6. Comparison of Average CO2 Absorption from the three treatments

Based on (Figure 4) above Sanseviera trifasciata leaf extract in $\mathrm{p} 2$ and p3 treatments showed a good decrease. Whereas in treatment 1 showed the lowest decrease in CO levels. But from the three treatments it was proven that Sanseviera trifasciata leaf extract was still effective in absorbing $\mathrm{CO}$ levels in cigarette smoke. 
This is in accordance with the opinion of Robi'atul, (2013) that the highest reduction found in the Sansevieria plant can reduce CO by $84.18 \%$.

\section{Conclusion}

Based on the results of research that has been done to reduce Sanseviera trifasciata leaf extract can reduce $\mathrm{CO}$ levels in cigarette smoke. Sanseviera trifasciata leaf extract with the administration of P2 obtained the average yield from the largest decrease in CO content, which was 91.11 ppm. Reducing CO levels in each Sanseviera trifasciata leaf extract has a limitation that is only able to absorb for 135 minutes. Hand bracelets containing Sanseviera trifasciata leaf extract with P3 arrangement can absorb CO by 37.89 ppm for every 15 minutes and work optimally for 135 minutes.

\section{Acknowledgment}

A big thank you to the Ministry of RISTEKDIKTI for funding our group's exact research program (PKM-PE) creativity program; Supervisor who always gives input in research activities; The lab. Biology University of Muhammadiyah Sukabumi (UMMI) which has provided facilities and support for research activities; Biology Education Study Program UMMI has provided a lot of technical and administrative assistance and other parties who have helped and been involved in this research activity. The author would like to thank KEMENRISTEKDIKTI, Lecturer, Biology education program, FKIP, Muhammadiyah University Sukabumi.

\section{References}

Adawiyah, A.R., Arindita, N.D \& Selviastuti, R. 2013. Panda Sansevieria trifasciata (Pengharum Ruangan Anti Debu dan Asap Rokok dengan Sistem Penetralisir Sirkulasi
Udara). Jurnal Ilmiah Mahasiswa. 3(1).

Bastiandy B. (2016). Mempersempit Gerak Perokok dengan Perda, http://mediaindonesia.com, diakses tanggal 25 Desember 2018.

Batubara, I. V. D., Wantouw, B., \& Tendean, L. (2013). Pengaruh Paparan Asap Rokok Kretek Terhadap Kualitas Spermatozoa Mencit Jantan (Mus musculus). EBiomedik, 1 (1) : 330-337.

Dewatisari, Whika F. (2014). Tingkat Kemampuan Berbagai Macam Kultivar Sanseviera trifasciata dalam Mereduksi Gas CO dari Asap Rokok. Laporan Penelitian Dosen Madya. Proyek Biologi dan Bioteknologi Umum. Fakultas Matematika dan Ilmu Pengetahuan Alam Universitas terbuka. Bandar lampung.

Julianto, E. \& Tjiptadi, J.A. 2015. Masker Lidah Mertua Penyerap Polutan Berbahaya Karya Siswa SMA. [Online]. Tersedia: http://ristekdikti.go.id. Diakses:14 Juni 2019.

Mahdalena, Ningsih, E. S. P., \& Noor, S. (2014). Pengaruh Rokok Terhadap Berat Badan Bayi Baru Lahir di RSUD Banjarbaru. Jurnal Skala Kesehatan, (5) 2.

Nurwaini, S., \& Saputri, I. D. (2018). Pengujian Sifat Fisik dan Aktivitas Antibakteri Sediaan Gel Hand Sanitizer Ekstrak Daun Lidah Mertua (Sansevieria trifasciata Prain). Talenta conference Series: Tropical Medicine (TM), (1) :78-85. https://doi.org/10.32734/tm.v1i3.266

Qodri, R. Al, BM, S., \& Riyanti, E. (2016). Beberapa faktor yang berhubungan dengan niat merokok siswa smp di kota semarang. Jurnal Kesehatan Masyarakat (e-Journal), (4) 3.

Robi'atul AA, dkk. 2013. Panda Sansevieria trifasciata (Pengharum Ruangan Anti Debu dan Asap Rokok Dengan Sistem Penetralisir Sirkulasi 
Udara). Jurnal Ilmiah Mahasiswa. 3(1).

Rosha, P. T., Fitriyana, M. N., Ulfa, S. F., \& Dharminto. (2013). Pemanfaatan Sansevieria Tanaman Hias Penyerap Polutan Sebagai Upaya Mengurangi Pencemaran Udara Di Kota Semarang. Jurnal Ilmiah Mahasiswa,
$3(1)$.

Sa'adah, H., \& Nurhasnawati, H. (2015). Perbandingan Pelarut Etanol dan Air pada Pembuatan Ekstrak Umbi Bawang Tiwai (Eleutherine americana Merr) Menggunakan Metode Maserasi. Jurnal Ilmiah Manuntung, 1(2), 149-153. 